\title{
神戸市薬剤師会所属薬剤師への災害救援活動に関する意識調査
}

\author{
安原智久, ${ }^{*}, a$ 近藤宏紀, ${ }^{a}$ 永田実沙, ${ }^{a}$ 岩田加奈, ${ }^{a}$ \\ 串畑太郎, $a$ 桂木聡子, $b, c$ 池内淳子, $d$ 曽根知道 ${ }^{a}$
}

\section{Survey on Disaster Relief Activities to the Pharmacists Belonging to Kobe-city Pharmaceutical Organization}

\author{
Tomohisa Yasuhara, ${ }^{*},{ }^{a}$ Hiroki Kondo, ${ }^{a}$ Misa Nagata, ${ }^{a}$ Kana Iwata, ${ }^{a}$ \\ Taro Kushihata, ${ }^{a}$ Satoko Katsuragi, ${ }^{b, c}$ Junko Ikeuchi, ${ }^{d}$ and Tomomichi Sone ${ }^{a}$ \\ ${ }^{a}$ Faculty of Pharmaceutical Sciences, Setsunan University; 45-1 Nagaotoge-cho, Hirakata, Osaka 573-0101, Japan: \\ ${ }^{b}$ School of Pharmacy, Hyogo University of Health Sciences; 1-3-6 Minatojima, Chuo-ku, Kobe 650-8530, Japan: \\ ${ }^{c}$ Kobe-city Pharmaceutical Organization; 6-4-3 Simoyamatedori, Chuo-ku, Kobe 650-0011, Japan: and ${ }^{d}$ Faculty of \\ Sciences and Engineering, Setsunan University; 17-8 Ikedanakamachi, Neyagawa, Osaka 572-8508, Japan.
}

(Received May 9, 2016; Accepted June 27, 2016; Advance publication released online July 22, 2016)

In 2014, there were about 160 thousands community pharmacists in Japan. Community pharmacists are health care workers who help victims in a disaster and are potential resources who can provide disaster relief. However, currently the disaster relief activities of community pharmacists are merely a resourceful and flexible demonstration of their professional abilities and not a specifically organized activity. Therefore, disaster relief education programs for community pharmacists are being explored and studies are still in the nascent stage. In this study, pharmacists of a pharmaceutical organization in Kobe City were asked to reply to a questionnaire survey so that their hopes and ideas about the disaster relief activities that they carry out can help build effective educational programs to enhance relief activities. Finally, 8 factors (cumulative contribution rate: 90.9\%) were extracted by factor analysis (maximum likelihood method, the diagonal elements: squared multiple correlation, quartimin rotation) of the 25 questions. In addition, a hierarchical cluster analysis (Ward method) by the factor scores of the extracted 8 factors resulted in 7 groups. The findings revealed the groups into which the community pharmacists were divided and their hopes and ideas about disaster relief. We expect that these results could bring awareness about the disaster relief activities suitable for each community pharmacist, provide appropriate training opportunities for those who volunteer, and motivate daily studies and preparations for disaster relief activities among community pharmacists.

Key words_— questionnaire survey; disaster relief; community pharmacist; factor analysis; cluster analysis

\section{は じめに}

保険調剤薬局及びドラッグストアにて地域医療・ 保険・福祉に従事する薬剤師（以下，薬局薬剤師） による大規模災害時における医療・生活支援が被災 者と他の医療従事者双方に対して有益であることが， 2011 年の東日本大震災での多くの薬局薬剤師の活 動1-9)により示された。また，2016 年に発生した熊 本地震においては，東日本大震災の経験を活かし て, 薬局薬剤師による迅速な医療・生活支援が展

$a$ 摂南大学薬学部, $b$ 兵庫医療大学薬学部, $c$ 神戸市薬剤 師会, $d$ 摄南大学理工学部

*e-mail: yasuhara@pharm.setsunan.ac.jp
開10,11)された。わが国において薬局薬剤師による災 害時の医療支援が定着をしてきたと言える。これら の事例が示す通り，災害時の健康・公衆衛生管理は 重要であり, 薬局薬荗師の果たす役割が大きいこと は明らかである，災害対策のマニュアルは整備12)さ れつつあるが，現状の薬局薬剤師の災害支援は使命 感・責任感に支えられた有志的な活動による部分が 大きく，薬局薬剤師全体を災害時の医療リソースと してどのように提供するかという制度の確立には至 っていない。一部の意欲ある薬局薬剤師の献身的な 活動によって支えられた支援は，いずれ息切れを起 こすことが予想され，13) 高く評価され始めた薬剤師 による災害支援活動の継続が困難になることが懸念 される，そうなる前に薬剤師全体としての災害支援 
の制度を整備し，薬学教育3,4,7,14,15) や薬剤師の生涯 学習7,16) として災害支援研修を取り入れる必要があ る.

災害時における薬剤師の支援活動は，災害派遣医 療チーム（disaster medical assistance team; DMAT) の一員や日本医師会災害医療チーム（Japan medical association team; JMAT) などと連携して被災地 に入り機動的・直接的に被災者に医療支援を行う事 例が注目されがちだが，これらに代表されるチーム の活動のみでは避難所及び被災地での避難者の生活 における健康・公衆衛生管理を発災の直後から行き 渡らせることは困難である。これらの健康・公衆衛 生管理は市民生活に近い医療職であり地域医療を広 く担う薬局薬剤師による支援が効果的と考えられ る。 また，被災地に派遣される薬局薬剤師の行うべ き派遣元での通常業務を分担する間接的な災害支 援7,17)も忘れてはならない。

2014 年における日本の薬局薬剤師は約 16 万人 ${ }^{18)}$ である．薬局薬剤師は災害時になんらかの形で支援 が可能な医療従事者であり，潜在的なリソースとし て大きな期待5,19,20)がされている，しかし，薬局薬 剂師が担う災害時の活動の実際は, 現場で職能を遺 憾なく発揮して柔軟かつ臨機応変に対応しているた め，一般論として具体的に整理されておらず，それ ゆえ，薬局薬剂師に対する組織的な災害時教育プロ グラム ${ }^{21,22)}$ は現在も模索段階にある。加えて，災害 時の薬局薬剂師の活動に関する報告は，経験を伝え る形となるため事例報告的になりがちである。この 形を否定するわけでは決してないが，本領域に関し てまとまった学術的な報告がいまだ少ないことが, 薬局薬剂師の災害支援に公的な説得力を持たせ難く している一面がある。

本研究では, 薬局薬剤師の災害支援に関する考え や傾向を明らかにするため, 神戸市薬剂師会の主催 する保険薬局・保険薬剤師伝達講習会に参加をした 薬剤師を対象として災害救援活動に関するアンケー 卜調査を行った.

\section{方法}

神戸市薬剂師会の主催する保険薬局・保険薬剂師 伝達講習会（2015 年 8 月 23 日，9月 6 日， 10 月 31 日，11月 7 日）にて「薬剤師の災害に対する意識 調査」の無記名アンケート（Fig. 1) を行った。ア
ンケートは講習会の入場時に配布し，調査に同意頂 ける場合にのみアンケートを薬剤師自らが退場時に 提出する方法で回収をした。調査の公正性，参加者 の自由意志での記載を担保するため，アンケートの 作成・解析は摂南大学薬学部が行い，配布・回収は 神戸市薬剤師会が行った。回収後, どの講習会で回 収されたアンケートか分からない状態で，回収した 全アンケートを神戸市薬剤師会から摂南大学に送付 した，解析手法として多変量解析を用いるため，多 変量解析で使用するアンケート項目に欠損のあるア ンケートは除外した。アンケートの統計学的解析に は JMP Pro 11.2 を用いた。

本研究は, 摂南大学医療研究倫理審査委員会の承 認を得て行った。

\section{結果}

4 日間の保険薬局・保険薬剂師伝達講習会の参加 者 1379 名にアンケートを配布し，その 806 名から アンケートを回収した。回収率は $58.5 \%$ であっ た。回収されたアンケートのうち 147 名分は多変量 解析に使用するアンケート項目に欠損があったため 解析から除外し，659名分を解析の対象とした。こ れは，2015 年 8 月での神戸市薬剤師会所属会員 1982 名の $33.2 \%$ であった. アンケートの単純集計 結果を Table 1 にまとめた。なお，対象とする 659 名のうち 657 名は Q4（複数選択可）において 1 若 しくは 2 を選択しており，保険調剂薬局若しくはド ラッグストア勤務の経験があった．残り 2 名は薬局 経営者としてその他を選択していた。

アンケート項目のうち，Q8-Q12 及び Q18-Q32 の 47 項目を用いて因子分析 ${ }^{23)}$ を行った。探索的因 子分析は，スクリープロットにより因子の固有值 1 以上を指標として，最尤法，対角要素を squared multiple correlation (SMC), Varimax 回転で行い, 最終的な共通性が 0.350 以上の項目を採用するこ と，また，どの因子に対しても因子負荷量が 0.450 未満の項目を排除することを基準に行った．最終的 に，25 項目を最尤法，対角要素を SMC，Quartimin 回転で因子分析を行い，Table 2 に示す 8 因子 を抽出した。累積寄与率は $90.9 \%$ であった。各因 子の示す特徴は以下の通りである.

因子 1 「防災教育 (Education)」：項目数 6. 寄与 率 $16.2 \%$ ，災害支援に関する研修や教育，情報の 


\section{「薬剂師の災害に対する意識調査」}

薬剂師の「災害及び災害医療に関する意識」について研究しております。災害支援について、率直な意見をお聞かせ ください。本調查の内容をご理解いただいた上で、調查に参加するか否かをあなたの自由な意志で決めてください。 参加されなくても不利益になることは一切ありません。なお、アンケートにお答えいただいたことにより、本調查に ご同意をいただいたこととなります。またアンケートの回収後には、個人は特定できないため、後から訂正・削除する ことは出来ません。アンケートに記入いただいた情報は、今回の調查目的以外に使用いたしません。記入いただいた 情報はコンピューターで処理を行い、個人が特定されないようにした上で、「薬剤師の災害支援の在り方」関する研究 や楽剂師教育に用いるほか、学会等で発表する場合があります。尚、その際に、個人を特定しうる情報の公開は一切 ありません。研究責任者： 摂南大学薬学部安原 智久 yasuhara@pharm.setsunan.ac.jp 兵庫医療大学薬学部 桂木 聡子

I .あなた自身に関することについてお伺いいたします。

Q1. 性別をお答えください

Q2. 年齢をお答えください

Q3. 薬鼡師勤務歴をお答えください

Q4. 職種をお答えください

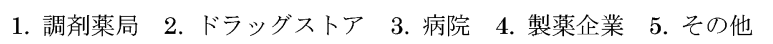

Q5. 世帯についてお答えください

1. 一人暮らし 2 . 二人以上で暮らしている

Q6. 子供はいますか? 1. いる 2. いない

Q7. 普段下記の情報媒体をどの程度使いますか?

$$
\text { インターネット }
$$

新聞

雑誌

TV

$$
\text { ラジオ }
$$

SNS(Facebook Twitter mixi 等)

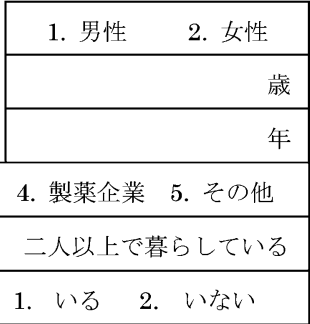

\section{IIご自身の経験等についてお尋ねします。}

Q8. 大きな災害にあわれた経験㤝ありますか?

Q.9 災害救援活動に参加した薬剤師の話をご存じですか?

Q10. 災害ボランティアで被災地を訪れた経験はありますか?

Q11. 薬珮師として被災地で災害救助活動に参加したことがありますか?

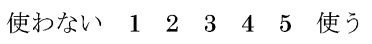

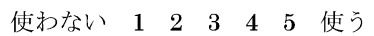

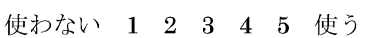

使わない $11 \quad 2 \quad 3 \quad 4 \quad 5 \quad$ 使う

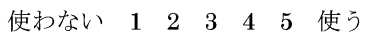

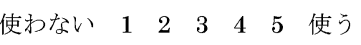

Q12. 災害を想定した訓練を受けたことがありますか？

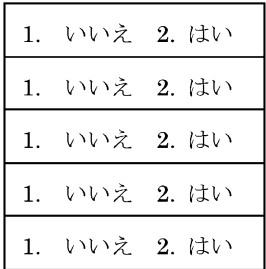

\section{吕.地震や災害救援活動に関することについてお伺いします。}

Q13. 㷋害救援活動で、薬剤師がどのようなことをするかご存じですか?

Q14. 薬剤師が災害時に活躍しているイメージはありますか?

1. いいえ2.はい

なし $\begin{array}{lllllll}1 & 2 & 3 & 4 & 5 & \text { ある }\end{array}$

Fig. 1. Questionnaire about Disaster Relief Activities

提供を求める設問及び災害支援参加のシステムを求 める項目.

因子 2 「参加意欲 (Motivation)」：項目数 3. 寄 与率 $14.5 \%$ ，災害支援への参加の意思を問う設問.

因子 3 「興味 - 関心 (Interest)」：項目数 4. 寄与
率 $13.9 \%$. 災害支援活動や被災地の状況への関心 に関する設問.

因子 4 「対人不安 (Interpersonal anxiety)」：項目 数 2 . 寄与率 $8.9 \%$ 。災害支援活動における被災者 や他の医療職との人間関係への不安に関する設問. 
Q15. 東南海・南海地震等が発生した時の災害救援活動では、どちらの医薬品が多く求められると思いますか?

1. 建物の倒壊などによる外傷等の急性疾患に対する医薬品

2. 糖尿病や高血圧等の慢性疾患に対する医薬品

Q16. 薬局・病院に何日分の薬を備蓄しておけば被苂した時に対応できると思いますか?

Q17. 東南海等の地震時に被災地の外から救援が来るまでどのくらい時間がかかると思いますか?

Q18. 薬剤師は炎害救援活動に参加する義務があると思いますか?

Q19. 薬㓲師は災害現場（避難所等）で役に立つと思いますか?

\begin{tabular}{|llllllll|}
\hline 思わない & 1 & 2 & 3 & 4 & 5 & 思う \\
\hline 思わない & 1 & 2 & 3 & 4 & 5 & 思う \\
\hline
\end{tabular}

IV防災関連のイベントや家での備えなどについてお聞きします。

Q20. 防災訓練や防災関連のイベントに参加したことがありますか?

Q21. 職場で防災訓練または防災関連のイベントは行われていますか?

Q22. 居住地域で防災訓練や防災関連のイベントは行われていますか?

Q23. 大きな災害に備えて個人としてなにか対策をしていますか?

Q24. 自宅の家具類の転倒・落下・移動に備えた対策をしていますか?

Q25. 災害時に備えて非常用品(食料や懐中電灯)などを自宅に備えていますか?

\begin{tabular}{|ccc|}
\hline 1. & いいえ & 2. はい \\
\hline 1. & いいえ & 2. はい \\
\hline 1. & いいえ & 2. はい \\
\hline 1. & いいえ & 2. はい \\
\hline 1. & いいえ & 2. はい \\
\hline 1. & いいえ & 2. はい \\
\hline
\end{tabular}

\section{V災害救援活動に関してお聞きします}

Q26. 大きな災害の際に自分自身の身と家族 恋人 友人などの安全が

確認できたら薬片師として地域の災害救援活動に参加しますか?

Q27. 要請があれば災害救援活動に参加しますか?

Q28. 知人や職場の人の誘いがあれば災害救援活動に参加しますか? Q29. 知人や職場の人が災害救援活動に参加することになったとして その人が災害救援活動に参加している間抜けた分の仕事を代わりに 引き受けますか?

\begin{tabular}{|lllllll|}
\hline しない & 1 & 2 & 3 & 4 & 5 & する \\
\hline \hline しない & 1 & 2 & 3 & 4 & 5 & する \\
\hline しない & 1 & 2 & 3 & 4 & 5 & する \\
\hline
\end{tabular}

しない $1 \begin{array}{llllll} & 2 & 3 & 4 & 5 & \text { する }\end{array}$

Q30. 下記のなかであなたにとって薬剤師として災害救援活動参加する理由になるものを教え下さい?
1. 被災者の役に立ちたい
2. 要請があるため
3. 薬剂師の知識が災害現場で役に立つ
4. 自分の受けた防災訓練や防災イベントでの知識が役に立つ
5. 災害救援活動に興味がある
6. 被苂地がどうなっているか気になる
7. 薬剤師として災害救援活動を経験してみたい
8. 知人や職場の人の誘いを受けた

\begin{tabular}{|llllllll|}
\hline ならない & 1 & 2 & 3 & 4 & 5 & なる \\
\hline ならない & 1 & 2 & 3 & 4 & 5 & なる \\
\hline ならない & 1 & 2 & 3 & 4 & 5 & なる \\
\hline ならない & 1 & 2 & 3 & 4 & 5 & なる \\
\hline ならない & 1 & 2 & 3 & 4 & 5 & なる \\
\hline ならない & 1 & 2 & 3 & 4 & 5 & なる \\
\hline ならない & 1 & 2 & 3 & 4 & 5 & なる \\
\hline ならない & 1 & 2 & 3 & 4 & 5 & なる \\
\hline
\end{tabular}

Fig. 1. (Continued)

因子 5「環境不安 (Environmental anxiety)」：項 目数 3. 寄与率 $8.9 \%$ 。被災地の環境や安全, 派遣 されている間の業務などへの不安に関する設問.

因子 6 「人的交流 (Human exchange)」: 項目数 3. 寄与率 $12.4 \%$ 。被災者や災害支援を経験した他
の薬剤師に関する設問.

因子 7 「個人対策 (Self prevention)」: 項目数 2 . 寄与率 $5.6 \%$ 個人レベルでの災害対策や自宅での 備えに関する設問。

因子 $8 「$ 使命 - 責任 (Mission)」項目数 2. 寄与 
Q31. もし明日大きな災害が居住地で起こって自分が地域の薬剤師として 災害救援活動参加することになったとして不安はありますか?その不安の程度について教えて下さい
1. 安全面の問題
2. 時間の問題
3. 衛生的な問題
4. 金銭的な問題
5. 災害救援活動の関する知識
6. 初めての参加による不安
7. 体力の不安
8. 災害救援活動行っている医療関係者との人閒関係
9. 被災者との人間関係
10. 残してきた家族やペットに対する不安
11. 職場の理解・業務への支障

\begin{tabular}{|lllllll|}
\hline ある & 1 & 2 & 3 & 4 & 5 & ない \\
\hline ある & 1 & 2 & 3 & 4 & 5 & ない \\
\hline ある & 1 & 2 & 3 & 4 & 5 & ない \\
\hline ある & 1 & 2 & 3 & 4 & 5 & ない \\
\hline ある & 1 & 2 & 3 & 4 & 5 & ない \\
\hline ある & 1 & 2 & 3 & 4 & 5 & ない \\
\hline ある & 1 & 2 & 3 & 4 & 5 & ない \\
\hline ある & 1 & 2 & 3 & 4 & 5 & ない \\
\hline ある & 1 & 2 & 3 & 4 & 5 & ない \\
\hline ある & 1 & 2 & 3 & 4 & 5 & ない \\
\hline ある & 1 & 2 & 3 & 4 & 5 & ない \\
\hline
\end{tabular}

Q32. 今後、災害救援活動に参加する薬剤師を増やすには何が必要だと思いますか?

1. 被災地での災害救援活動にかかる費用の支給

2. 薬剤師の災害救援活動に関する情報の充実

3. 被災地からの感謝の声などのフィードバック

4. 被災経験者との交流

5. 災害救援活動に参加した薬剂師との交流

6. 薬剂師向けの防災訓練や防災イベントを増やす

7. 薬剂師の災害救援活動に対する報酬の確立

8. 簡単に薬剤師が災害救援活動に参加できる仕組み

9. 被災地に行かなくても貢献できる作業内容を増やす

10. 薬学教育の中に災害救援活動に関する情報を取り込むこと

11. 薬剂師の災害救援活動に関する勉強

\begin{tabular}{|llllllll|}
\hline 不必要 & 1 & 2 & 3 & 4 & 5 & 必要 \\
\hline 不必要 & 1 & 2 & 3 & 4 & 5 & 必要 \\
\hline 不必要 & 1 & 2 & 3 & 4 & 5 & 必要 \\
\hline 不必要 & 1 & 2 & 3 & 4 & 5 & 必要 \\
\hline 不必要 & 1 & 2 & 3 & 4 & 5 & 必要 \\
\hline 不必要 & 1 & 2 & 3 & 4 & 5 & 必要 \\
\hline 不必要 & 1 & 2 & 3 & 4 & 5 & 必要 \\
\hline 不必要 & 1 & 2 & 3 & 4 & 5 & 必要 \\
\hline 不必要 & 1 & 2 & 3 & 4 & 5 & 必要 \\
\hline 不必要 & 1 & 2 & 3 & 4 & 5 & 必要 \\
\hline 不必要 & 1 & 2 & 3 & 4 & 5 & 必要 \\
\hline
\end{tabular}

アンケートご協力ありがとうございました。

Fig. 1. (Continued)

率 $10.4 \%$ ，薬剤師としての義務感や使命感に関す る設問。

また，抽出した 8 つ因子の因子得点により，階 層型クラスター分析（Ward 法）を行い $\mathrm{A}-\mathrm{G}$ の 7 群に分類した（Fig. 2). 各群の持つ因子得点の平
均を Table 3 に示した。さらに，7群毎の性別 $(\mathrm{Q} 1)$ ，年齢 $(\mathrm{Q} 2)$ ，薬剂師歴 $(\mathrm{Q} 3)$ ，一人暮らしか 否か（Q5），子供の有無（Q6），被災時に必要な医 薬品の備蓄量（Q16）, 外部救援の到着までの日数 （Q17）を Table 4 に，情報媒体の使用程度（Q7.1- 
Table 1. Simple Tabulation of the Questionnaire

\begin{tabular}{|c|c|c|c|c|c|}
\hline Q1. & \multicolumn{3}{|c|}{ Male: 91 , Female: 568} & & \\
\hline Q2. & \multicolumn{3}{|c|}{$46.1 \pm 11.1$ (years, mean \pm S.D. $)$} & & \\
\hline Q3. & \multicolumn{3}{|c|}{$17.5 \pm 9.7$ (years, mean \pm S.D. $)$} & & \\
\hline & 1 & 2 & 3 & 4 & 5 \\
\hline Q4. & 643 & 18 & 20 & 6 & 9 \\
\hline Q5. & \multicolumn{3}{|c|}{ Single life: 95 , Others: 564} & & \\
\hline Q6. & \multicolumn{3}{|c|}{ With child (ren) : 408, Others: 249} & & \\
\hline Q7. & 1 & 2 & 3 & 4 & 5 \\
\hline Q7.1 & 17 & 33 & 103 & 113 & 392 \\
\hline Q7.2 & 171 & 81 & 163 & 89 & 151 \\
\hline Q7.3 & 146 & 164 & 210 & 72 & 58 \\
\hline Q7.4 & 31 & 52 & 189 & 159 & 224 \\
\hline Q7.5 & 447 & 90 & 68 & 20 & 23 \\
\hline \multirow[t]{2}{*}{ Q7.6 } & 369 & 59 & 78 & 58 & 85 \\
\hline & \multicolumn{2}{|l|}{$1(\mathrm{No})$} & $2($ Yes) & & \\
\hline Q8. & \multicolumn{2}{|l|}{206} & 453 & & \\
\hline Q9. & \multicolumn{2}{|l|}{185} & 474 & & \\
\hline Q10. & \multicolumn{2}{|l|}{616} & 43 & & \\
\hline Q11. & \multicolumn{2}{|l|}{624} & 35 & & \\
\hline Q12. & \multicolumn{2}{|l|}{585} & 74 & & \\
\hline Q13. & \multicolumn{2}{|l|}{287} & 368 & & \\
\hline & 1 & 2 & 3 & 4 & 5 \\
\hline \multirow[t]{2}{*}{ Q14. } & 62 & 135 & 250 & 121 & 91 \\
\hline & \multicolumn{2}{|l|}{1} & 2 & & \\
\hline Q15. & \multicolumn{2}{|l|}{137} & 400 & & \\
\hline Q16. & \multicolumn{3}{|c|}{$29.1 \pm 36.5(\mathrm{~d}$, mean \pm S.D. $)$} & & \\
\hline \multirow[t]{2}{*}{ Q17. } & \multicolumn{3}{|c|}{$4.4 \pm 5.3(\mathrm{~d}$, mean \pm S.D. $)$} & & \\
\hline & 1 & 2 & 3 & 4 & 5 \\
\hline Q18. & 12 & 25 & 208 & 185 & 229 \\
\hline \multirow[t]{2}{*}{ Q19. } & 18 & 43 & 182 & 194 & 222 \\
\hline & $1(\mathrm{No})$ & & 2 (Yes) & & \\
\hline Q20. & 472 & & 187 & & \\
\hline Q21. & 604 & & 55 & & \\
\hline Q22. & 357 & & 302 & & \\
\hline Q23. & 388 & & 271 & & \\
\hline Q24. & 343 & & 316 & & \\
\hline Q25. & 285 & & 374 & & \\
\hline
\end{tabular}

\begin{tabular}{|c|c|c|c|c|c|}
\hline & 1 & 2 & 3 & 4 & 5 \\
\hline Q26. & 48 & 72 & 258 & 169 & 112 \\
\hline Q27. & 49 & 57 & 218 & 186 & 149 \\
\hline Q28. & 39 & 51 & 229 & 201 & 139 \\
\hline Q29. & 14 & 26 & 140 & 177 & 302 \\
\hline Q30. & 1 & 2 & 3 & 4 & 5 \\
\hline Q30.1 & 16 & 27 & 152 & 210 & 254 \\
\hline Q30.2 & 27 & 32 & 229 & 204 & 167 \\
\hline Q30.3 & 18 & 43 & 192 & 225 & 181 \\
\hline Q30.4 & 99 & 100 & 268 & 119 & 73 \\
\hline Q30.5 & 96 & 95 & 285 & 110 & 73 \\
\hline Q30.6 & 76 & 70 & 259 & 143 & 111 \\
\hline Q30.7 & 85 & 94 & 261 & 141 & 78 \\
\hline Q30.8 & 113 & 73 & 269 & 132 & 72 \\
\hline Q31. & 1 & 2 & 3 & 4 & 5 \\
\hline Q31.1 & 295 & 206 & 117 & 23 & 18 \\
\hline Q31.2 & 276 & 208 & 139 & 19 & 17 \\
\hline Q31.3 & 271 & 212 & 133 & 32 & 11 \\
\hline Q31.4 & 194 & 135 & 217 & 75 & 38 \\
\hline Q31.5 & 330 & 159 & 133 & 20 & 17 \\
\hline Q31.6 & 379 & 150 & 91 & 15 & 24 \\
\hline Q31.7 & 320 & 144 & 116 & 42 & 37 \\
\hline Q31.8 & 153 & 156 & 207 & 71 & 72 \\
\hline Q31.9 & 164 & 147 & 217 & 64 & 67 \\
\hline Q31.10 & 345 & 115 & 102 & 40 & 57 \\
\hline Q31.11 & 302 & 139 & 151 & 35 & 32 \\
\hline Q32. & 1 & 2 & 3 & 4 & 5 \\
\hline Q32.1 & 14 & 16 & 123 & 199 & 307 \\
\hline Q32.2 & 1 & 2 & 57 & 192 & 407 \\
\hline Q32.3 & 52 & 60 & 228 & 164 & 155 \\
\hline Q32.4 & 35 & 47 & 251 & 183 & 143 \\
\hline Q32.5 & 14 & 23 & 163 & 229 & 230 \\
\hline Q32.6 & 14 & 23 & 162 & 254 & 206 \\
\hline Q32.7 & 30 & 38 & 212 & 194 & 185 \\
\hline Q32.8 & 7 & 6 & 124 & 217 & 305 \\
\hline Q32.9 & 2 & 8 & 113 & 189 & 347 \\
\hline Q32.10 & 4 & 13 & 155 & 209 & 278 \\
\hline Q32.11 & 2 & 7 & 127 & 213 & 310 \\
\hline
\end{tabular}


Table 2. Factor Loading after Rotation

\begin{tabular}{|c|c|c|c|c|c|c|c|c|c|c|}
\hline Factor name & Question & Communality & Factor 1 & Factor 2 & Factor 3 & Factor 4 & Factor 5 & Factor 6 & Factor 7 & Factor 8 \\
\hline \multirow[t]{6}{*}{ Education } & Q32.11 & 0.641 & 0.827 & -0.029 & 0.076 & -0.046 & 0.059 & -0.100 & -0.018 & 0.041 \\
\hline & Q32.10 & 0.605 & 0.780 & -0.077 & 0.095 & 0.042 & 0.041 & 0.017 & -0.001 & -0.017 \\
\hline & Q32.9 & 0.394 & 0.621 & 0.002 & -0.009 & -0.043 & -0.082 & -0.064 & 0.000 & 0.009 \\
\hline & Q32.8 & 0.436 & 0.545 & 0.142 & -0.037 & -0.030 & -0.045 & 0.103 & 0.004 & 0.000 \\
\hline & Q32.6 & 0.479 & 0.545 & -0.010 & 0.021 & -0.029 & 0.037 & 0.198 & -0.002 & 0.085 \\
\hline & Q32.2 & 0.365 & 0.536 & 0.069 & -0.066 & 0.059 & -0.095 & 0.084 & 0.021 & -0.020 \\
\hline \multirow[t]{3}{*}{ Motivation } & Q27 & 0.895 & -0.003 & 0.946 & 0.003 & 0.023 & 0.004 & -0.018 & -0.017 & -0.004 \\
\hline & Q28 & 0.843 & 0.036 & 0.901 & 0.008 & -0.011 & 0.028 & -0.010 & -0.016 & 0.007 \\
\hline & Q26 & 0.650 & -0.041 & 0.711 & 0.113 & 0.009 & 0.009 & -0.003 & 0.032 & 0.089 \\
\hline \multirow[t]{4}{*}{ Interest } & Q30.5 & 0.817 & 0.013 & -0.005 & 0.928 & 0.022 & 0.032 & -0.061 & 0.009 & -0.030 \\
\hline & Q30.6 & 0.520 & 0.021 & -0.049 & 0.704 & -0.005 & -0.019 & 0.076 & 0.002 & 0.016 \\
\hline & Q30.7 & 0.584 & 0.028 & 0.151 & 0.646 & -0.036 & 0.036 & 0.027 & -0.048 & 0.039 \\
\hline & Q30.4 & 0.380 & -0.007 & 0.035 & 0.591 & 0.017 & -0.049 & 0.014 & 0.023 & 0.011 \\
\hline \multirow{2}{*}{$\begin{array}{l}\text { Interpersonal } \\
\text { anxiety }\end{array}$} & Q31.9 & 1.000 & 0.007 & -0.040 & -0.001 & 1.024 & -0.016 & 0.039 & -0.016 & 0.007 \\
\hline & Q31.8 & 0.609 & -0.015 & 0.049 & 0.018 & 0.730 & 0.036 & -0.068 & 0.005 & 0.013 \\
\hline \multirow{3}{*}{$\begin{array}{l}\text { Environmental } \\
\text { anxiety }\end{array}$} & Q31.1 & 0.612 & -0.028 & -0.061 & -0.023 & -0.023 & 0.773 & -0.043 & -0.044 & 0.060 \\
\hline & Q31.3 & 0.555 & 0.013 & -0.017 & 0.003 & 0.048 & 0.720 & -0.026 & 0.041 & 0.001 \\
\hline & Q31.2 & 0.361 & -0.013 & 0.087 & -0.002 & 0.014 & 0.586 & 0.046 & 0.011 & -0.051 \\
\hline \multirow[t]{3}{*}{ Human exchange } & Q32.4 & 0.847 & 0.001 & -0.019 & 0.038 & 0.009 & 0.018 & 0.914 & -0.004 & 0.024 \\
\hline & Q32.3 & 0.412 & -0.025 & -0.019 & 0.066 & -0.096 & -0.073 & 0.573 & -0.014 & 0.005 \\
\hline & Q32.5 & 0.533 & 0.329 & 0.083 & -0.014 & -0.010 & 0.021 & 0.482 & 0.020 & 0.033 \\
\hline \multirow[t]{2}{*}{ Self prevention } & Q25 & 0.982 & -0.029 & -0.035 & -0.012 & 0.021 & 0.008 & 0.061 & 0.990 & -0.028 \\
\hline & Q23 & 0.398 & 0.013 & 0.015 & 0.014 & -0.023 & 0.000 & -0.047 & 0.628 & 0.023 \\
\hline \multirow[t]{2}{*}{ Mission } & Q18 & 0.843 & 0.054 & 0.046 & -0.050 & 0.017 & 0.019 & 0.020 & 0.048 & 0.890 \\
\hline & Q19 & 0.527 & -0.038 & -0.008 & 0.037 & 0.004 & -0.019 & -0.011 & -0.027 & 0.728 \\
\hline \multicolumn{3}{|c|}{ Contribution rate } & 16.2 & 14.5 & 13.9 & 8.9 & 8.9 & 12.4 & 5.6 & 10.4 \\
\hline \multicolumn{3}{|c|}{ Cumulative contribution ratio } & 16.2 & 30.7 & 44.6 & 53.5 & 62.4 & 74.9 & 80.5 & 90.9 \\
\hline
\end{tabular}

Q7.6）及び災害支援薬剤師の日常業務の代行（Q29） を Table 5 に示した. 各群の特徵は以下の通りであ る.

$\mathrm{A}$ 群：141 人 $21.4 \%$ 。ほとんどの因子が平均以 下．災害支援に対してほとんど興味がなく，自らが 何かをする具体性を感じていない層. 情報メディア の活用が他の群に比べて低い傾向がある.

B 群 : 70 人 $10.6 \%$ 。災害支援に全く興味はない ため災害支援時の不安も少ない層．平均年齢が高 め．情報メディアの活用が他の群に比べて低い傾向 がある．災害支援に行った他者の業務支援に関する 意欲も低い.

$\mathrm{C}$ 群 : 179 人 $27.2 \%$. 平均的な興味を示し, 自己 の備えは怠っていない層。平均年齢が高めで， $\mathrm{E}$ 群 に対して最も差がみられた（Tukey-Kramer 検定, $p=0.3482$ ).
$\mathrm{D}$ 群 : 33 人 $5.0 \%$. 使命感と意欲が高いが，学習 の必要性は低く, 被災地支援に関する不安が著しく 低い層．平均年齢が低めで，他の群に比べて女性が 多い.

$\mathrm{E}$ 群：107人 $16.2 \%$ 。教育の必要性, 意欲, 興 味，使命感，交流が高いが不安は平均的な層。平均 年齢が低めで，C 群に対して最も差がみられた (Tukey-Kramer 検定, $p=0.3482$ ). インターネット,

SNS，テレビを活用する割合が高い.

$\mathrm{F}$ 群 : 50 人 $7.6 \%$ 。教育の必要性，使命感，交 流，災害への備えが高く不安の高い層．テレビ，新 聞，雑誌を活用する割合が高い。

$\mathrm{G}$ 群 : 79 人 $12.0 \%$ 。教育の必要性と交流が高く 興味も平均的だが不安が強く, 意欲や使命感の低い 層. 情報メディアの活用に関しては平均的である. 


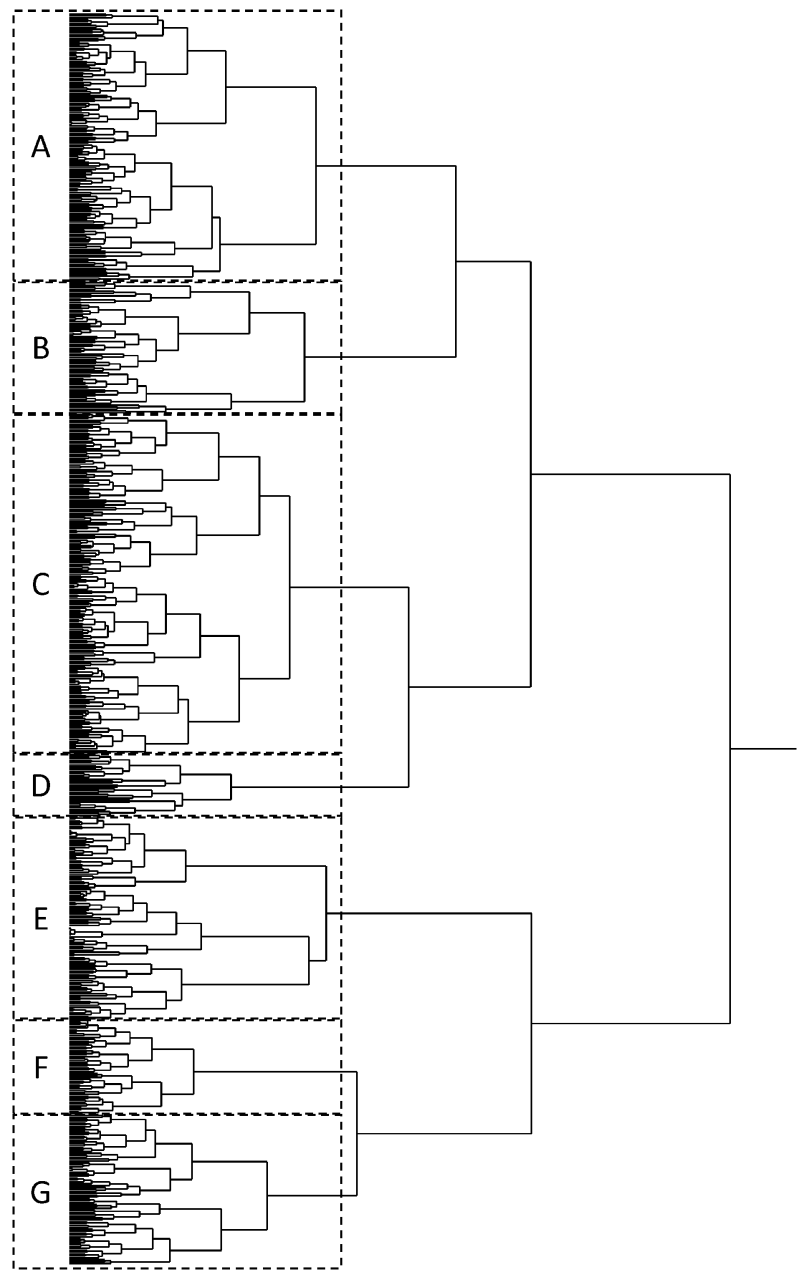

Fig. 2. Results of the Cluster Analysis

\section{考察}

本研究は, アンケート調査を神戸市薬剤師会の会 員を対象に行っているため, 結果及び考察に地域的 な特性が現れると考えられる。1995 年の阪神・淡 路大震災を経験した土地であるがゆえに防災意識は 高く，地域一帯となった訓練も盛んである，薬局薬 剂師も他地域に比較して，防災訓練・イベントに参 加した率が高いことが予想され，また自治体などに よる意識づけも高いと考えられる。 また，本アン ケートの配布及び回収は，災害に関連した行事では なく，また参加要件や制限のない保険薬局・保険薬 剤師伝達講習会で行っているため, アンケート配布 対象者によるバイアスが入り難いと考えられる．有 効回答数は神戸市薬剤師会全会員の約 3 分の 1 であ るため，母集団の傾向を適切に反映したものとなつ ていると考えられる.
単純集計（Table 1) から，アンケート回答者は 86.2\%が女性，平均年齢が 46.1 歳であり，これは 2014 年度における全国の薬局薬剤師の女性の割合 である $90.0 \%$ ，平均年齢である 46.3 歳と大きく変 わらなかった. ${ }^{17)}$ 本結果は，性別，年齢の観点では 全国との差異は少ないと考えられる，また，因子分 析の対象者は薬局経営者と答えた薬剤師も含めれば 全員が薬局薬剤師経験者であるため，本結果を薬局 薬剂師の傾向と捉えることが可能と考えられる.さ らに，特に 1 つの選択肢に偏つたり，凹型の分布を 示したりする設問がないことから，各設問を因子分 析に用いることに大きな支障はないと考えられる.

クラスター分析による群分けと，それぞれの群が 持つ因子の性質（Table 3)，さらには因子分析に用 いなかったアンケート項目の群間の差（Table 4） から各群の特性を検討した。群は，「Q32。救援活 動に参加する薬剤師を増やすには何が必要だと思い ますか?」という設問中の「薬剤師に対する災害教 育や災害支援活動に対する研修（因子 1)」と「支 援対象者や支援経験者との人的な交流（因子 6)」 の 2 項目の回答によって大きく2つにわかれた。こ れらの必要性が低いと考える群（A-D 群）は 423 人, $64.2 \%$ でり, 必要性が高いと考える群 $(\mathrm{E}-\mathrm{G}$ 群）は 236 人， $35.8 \%$ あ゙る．前者には，既に十分 な支援や交流があるからこれ以上のものは必要ない と考える可能性もあるが，A-C 群では，災害支援 へのモチベーションや興味も低い傾向であることを 合わせて考えると，薬局薬剂師が災害支援に十分な 準備ができていると考えているわけではないと思わ れる，災害ということに関して全体的に関心が低い と思われる $\mathrm{A}$ 群と, 自身の防災意識のみが高いと 思われる B 群の差はみられるが，両群合わせた約 3 分の 1 が薬剤師による災害支援に関して関心が低い と思われる。

一方 C 群は，自身の防災意識が高く他の因子は 平均的である。災害支援における薬局薬剤師に関す る情報が不足しており，判断がつかない可能性が高 い.この群は最も数が多く災害支援に対して否定的 でもないため，研修等による影響が大きく出やすい 層であると考えられる，D群は学習の機会や当事 者との交流を必要だと考えていないが，被災地支援 への意欲が高く支援に関する不安も著しく低い。災 害支援に対して過剩に楽観的である可能性が考えら 
Table 3. Factor Scores of Each Group

\begin{tabular}{|c|c|c|c|c|c|c|c|}
\hline Group & A & B & $\mathrm{C}$ & $\mathrm{D}$ & $\mathrm{E}$ & $\mathrm{F}$ & G \\
\hline \multirow{3}{*}{ Number } & \multicolumn{4}{|c|}{$423(64.2 \%)$} & \multicolumn{3}{|c|}{$236(35.8 \%)$} \\
\hline & \multicolumn{2}{|c|}{$211(32.0 \%)$} & \multicolumn{2}{|c|}{$212(32.2 \%)$} & $107(16.2 \%)$ & \multicolumn{2}{|c|}{$129(19.6 \%)$} \\
\hline & $141(21.4 \%)$ & $70(10.6 \%)$ & $179(27.2 \%)$ & $33(5.0 \%)$ & $107(16.2 \%)$ & $50(7.6 \%)$ & $79(12.0 \%)$ \\
\hline Factor 1 & $-0.51 \pm 0.68$ & $-1.24 \pm 0.81$ & $0.04 \pm 0.72$ & $-0.37 \pm 0.93$ & $0.88 \pm 0.39$ & $0.61 \pm 0.66$ & $0.48 \pm 0.63$ \\
\hline Factor 2 & $-0.18 \pm 0.85$ & $-1.00 \pm 0.99$ & $0.03 \pm 0.70$ & $0.71 \pm 0.85$ & $1.00 \pm 0.58$ & $0.28 \pm 0.63$ & $-0.69 \pm 0.75$ \\
\hline Factor 3 & $-0.26 \pm 0.75$ & $-0.82 \pm 0.81$ & $-0.04 \pm 0.80$ & $-0.26 \pm 0.82$ & $1.09 \pm 0.75$ & $0.14 \pm 0.71$ & $-0.18 \pm 0.78$ \\
\hline Factor 4 & $0.04 \pm 0.81$ & $0.50 \pm 0.90$ & $0.26 \pm 0.83$ & $1.15 \pm 0.75$ & $0.05 \pm 1.12$ & $-1.02 \pm 0.40$ & $-1.01 \pm 0.53$ \\
\hline Factor 5 & $0.04 \pm 0.74$ & $0.40 \pm 0.79$ & $0.04 \pm 0.66$ & $1.94 \pm 0.73$ & $-0.16 \pm 0.80$ & $-0.69 \pm 0.43$ & $-0.68 \pm 0.57$ \\
\hline Factor 6 & $-0.46 \pm 0.67$ & $-1.03 \pm 0.86$ & $0.04 \pm 0.75$ & $-0.69 \pm 0.85$ & $0.72 \pm 0.76$ & $0.67 \pm 0.64$ & $0.53 \pm 0.70$ \\
\hline Factor 7 & $-1.14 \pm 0.06$ & $0.61 \pm 0.61$ & $0.86 \pm 0.06$ & $0.16 \pm 1.00$ & $-0.40 \pm 0.96$ & $0.90 \pm 0.05$ & $-0.53 \pm 0.93$ \\
\hline Factor 8 & $-0.37 \pm 0.82$ & $-0.71 \pm 0.98$ & $-0.05 \pm 0.74$ & $0.33 \pm 0.99$ & $1.03 \pm 0.31$ & $0.64 \pm 0.42$ & $-0.53 \pm 0.78$ \\
\hline
\end{tabular}

mean \pm S.D.

Table 4. Cross Tabulation of Groups versus Questionnaires about Key Properties

\begin{tabular}{|c|c|c|c|c|c|c|c|c|c|}
\hline & Question & Unit & A & B & $\mathrm{C}$ & $\mathrm{D}$ & $\mathrm{E}$ & $\mathrm{F}$ & G \\
\hline \multirow{2}{*}{ Q1. } & Male & $(n)$ & 19 & 12 & 22 & 9 & 18 & 5 & 6 \\
\hline & Female & $(n)$ & 122 & 58 & 157 & 24 & 89 & 45 & 73 \\
\hline \multirow{2}{*}{$\begin{array}{l}\text { Q2. } \\
\text { Q3. }\end{array}$} & Age & （years） & $45.9 \pm 11.2$ & $47.7 \pm 12.2$ & $47.4 \pm 9.9$ & $44.3 \pm 10.4$ & $44.5 \pm 11.9$ & $46.5 \pm 11.1$ & $44.9 \pm 11.4$ \\
\hline & Career & （years） & $17.3 \pm 9.6$ & $19.3 \pm 10.9$ & $17.9 \pm 9.4$ & $16.7 \pm 8.4$ & $17.2 \pm 11.1$ & $16.9 \pm 8.5$ & $16.7 \pm 8.1$ \\
\hline \multirow{2}{*}{ Q5. } & Single life & $(n)$ & 28 & 12 & 15 & 6 & 20 & 2 & 12 \\
\hline & Others & $(n)$ & 113 & 57 & 164 & 27 & 87 & 48 & 67 \\
\hline \multirow{2}{*}{ Q6. } & With child (ren) & $(n)$ & 82 & 48 & 121 & 18 & 58 & 37 & 44 \\
\hline & Others & $(n)$ & 58 & 21 & 58 & 15 & 49 & 13 & 35 \\
\hline Q16. & Stores & (d) & $32.9 \pm 36.6$ & $28.1 \pm 48.3$ & $25.8 \pm 35.9$ & $23.4 \pm 23.2$ & $30.8 \pm 38.5$ & $28.4 \pm 28.2$ & $31.7 \pm 31.6$ \\
\hline Q17. & Supports & (d) & $3.9 \pm 4.6$ & $4.1 \pm 3.1$ & $4.6 \pm 6.2$ & $4.0 \pm 2.0$ & $4.1 \pm 4.5$ & $4.5 \pm 3.0$ & $5.3 \pm 8.5$ \\
\hline
\end{tabular}

Q2, 3, 16, 17: mean \pm S.D.

れる。

その一方で， $\mathrm{E}$ 及び $\mathrm{F}$ 群は，前者が被災地支援 への不安が少なく自身の災害対策が低い，後者は被 災地支援への不安が強いという傾向が異なるもの の，災害支援に対する研修や制度の必要性や意欲, 薬剤師としての使命感が高い。また情報収集に対し て多様なメディアを活用することに積極的である. 最も活動的な支援者となる可能性が高い層である. $\mathrm{G}$ 群は災害支援に対する学習意欲や興味は高い が，使命・責任感が低い傾向がみられるため実際の 活動への移行には時間がかかる可能性が考えられる.

災害支援に関する薬局薬剤師の役割は比較的新し い議論のため，そのあり方に対する意識は多様であ ると考えられるが，今回の調査で多様な薬局薬剤師 のあり方を具体的に示すことができた。黎明期から
本格的な発展期へと移行した薬局薬剂師による災害 支援は，その教育研修のあり方も変化が求められる と考えられる。一部の意欲ある層をターゲットにし た高度で実践的な研修は無論これまで通り必要であ るが，災害支援への興味を自己研鑚の意欲に変えて いく，裾野の広い研修もまた必要になっていくと考 えられる．また，現在の薬局薬剤師にはこれだけ多 様な層がみられることからも，ある研修の成果を議 論するにあたっては，その研修のターゲットとする 層や学習目標，そして実際に研修に参加した薬剤師 の層を合わせて議論しなければ，研修の是非が問え ないことも示唆された.

繰り返される災害とその支援経験から，被災地で は災害時の医療支援に加えて，生活支援や避難所で の健康・公衆衛生の管理が重要視24-26) されている. 
Table 5. Cross Tabulation of Groups versus Questionnaires about Information and Support of Daily Work

\begin{tabular}{crrrrr}
\multicolumn{2}{l}{ Q7.1 Use of internet } \\
\hline Group & 1 & \multicolumn{1}{l}{ 2 } & \multicolumn{1}{l}{3} & \multicolumn{1}{c}{4} & \multicolumn{1}{c}{5} \\
\hline A & 3 & 11 & 24 & 34 & 69 \\
B & 1 & 5 & 18 & 8 & 38 \\
C & 2 & 8 & 32 & 37 & 99 \\
D & 1 & 1 & 5 & 2 & 24 \\
E & 2 & 2 & 10 & 12 & 81 \\
F & 4 & 1 & 4 & 8 & 33 \\
G & 4 & 5 & 10 & 12 & 48 \\
\hline
\end{tabular}

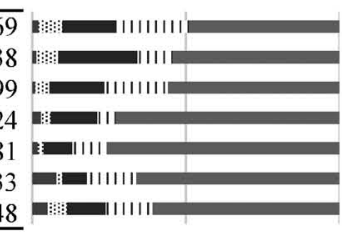

Q7.2 Use of newspaper

\begin{tabular}{crrrrr}
\hline Group & 1 & \multicolumn{1}{c}{2} & \multicolumn{1}{c}{4} & \multicolumn{1}{c}{5} \\
\hline A & 38 & 16 & 39 & 27 & 21 \\
B & 21 & 10 & 21 & 7 & 11 \\
C & 38 & 22 & 49 & 23 & 47 \\
D & 11 & 5 & 5 & 5 & 7 \\
E & 36 & 15 & 19 & 9 & 25 \\
F & 8 & 4 & 11 & 10 & 16 \\
G & 19 & 9 & 19 & 8 & 24
\end{tabular}

Q7.3 Use of magazine

\begin{tabular}{|c|c|c|c|c|c|c|}
\hline Group & 1 & 2 & 3 & 4 & 5 & \\
\hline $\mathrm{A}$ & 3 & 11 & 24 & 34 & 69 & It: \\
\hline B & 1 & 5 & 18 & 8 & 38 & 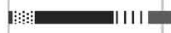 \\
\hline $\mathrm{C}$ & 2 & 8 & 32 & 37 & 99 & It: \\
\hline D & 1 & 1 & 5 & 2 & 24 & || \\
\hline $\mathrm{E}$ & 2 & 2 & 10 & 12 & 81 & \\
\hline $\mathrm{F}$ & 4 & 1 & 4 & 8 & 33 & E:m|॥ा \\
\hline $\mathrm{G}$ & 4 & 5 & 10 & 12 & 48 & 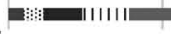 \\
\hline
\end{tabular}

Q7.4 Use of television

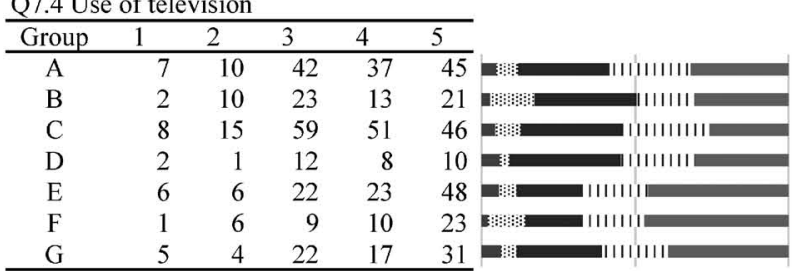

Q7.5 Use of radio

\begin{tabular}{crrrrr}
\hline Group & \multicolumn{1}{c}{1} & \multicolumn{1}{c}{3} & \multicolumn{1}{l}{4} & \multicolumn{1}{c}{5} \\
\hline A & 112 & 14 & 11 & 1 & 3 \\
B & 45 & 9 & 9 & 1 & 3 \\
C & 114 & 33 & 22 & 5 & 3 \\
D & 19 & 7 & 4 & 1 & 2 \\
E & 72 & 12 & 9 & 6 & 6 \\
F & 29 & 7 & 5 & 4 & 3 \\
G & 56 & 8 & 8 & 2 & 3 \\
\hline
\end{tabular}
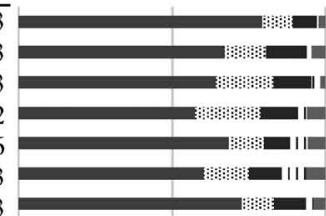

Q7.6 Use of SNS

\begin{tabular}{|c|c|c|c|c|c|c|}
\hline Group & 1 & 2 & 3 & 4 & 5 & \\
\hline $\mathrm{A}$ & 83 & 16 & 11 & 15 & 14 & 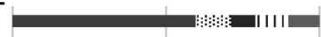 \\
\hline B & 44 & 4 & 7 & 5 & 8 & DE \\
\hline $\mathrm{C}$ & 105 & 18 & 25 & 13 & 18 & 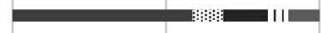 \\
\hline D & 21 & 1 & 6 & 4 & 1 & a IIIII \\
\hline $\mathrm{E}$ & 45 & 4 & 20 & 9 & 27 & $\because$ \\
\hline $\mathrm{F}$ & 26 & 10 & 1 & 4 & 8 & mbetan I I \\
\hline $\mathrm{G}$ & 45 & 6 & 8 & 8 & 9 & aIII \\
\hline
\end{tabular}

Q29. Support of daily work

\begin{tabular}{|c|c|c|c|c|c|c|}
\hline Group & 1 & 2 & 3 & 4 & 5 & \\
\hline $\mathrm{A}$ & 6 & 3 & 36 & 47 & 49 & E: \\
\hline B & 6 & 12 & 26 & 10 & 16 & 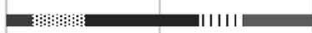 \\
\hline $\mathrm{C}$ & 1 & 5 & 35 & 56 & 82 & : \\
\hline D & 0 & 1 & 5 & 5 & 22 & - $1111 \|$ \\
\hline $\mathrm{E}$ & c & 0 & 5 & 20 & 82 & EIIIIIIE \\
\hline $\mathrm{F}$ & c & 0 & 10 & 14 & 26 & {$[\|\|\|\|\|\|$} \\
\hline G & 1 & 5 & 23 & 25 & 25 & - 111111111111 \\
\hline
\end{tabular}

一方で，災害時における薬局薬剂師の有用性が広く 認められ，薬局薬凨師の活動が今回の熊本地震では 広く報道27)されている，薬局薬剂師は災害時に何が できるのかという議論の段階は既に終わり，今後 は，薬局薬剤師の職能をどこでどのように発揮する べきかという議論が活発になっていくと思われる. 実際，薬剂師を対象とした災害時研修は，日本集団 災害医学会22)や日本災害医療薬剤師学会23)によって 認定資格化されたものが組織的に提供されているほ か，様々な試みが行われている。しかしながら，災 害時における支援は多様にあり，誰がごの支援を 行っても被災地・被災者に対して適切な貢献ができ るわけではない，今回の，神戸市薬剤師会に対する 調査により，薬局薬剤師の災害支援に対する考え方 を基にどのような希望・志向を持った群が存在する かを明らかにした。本結果が，薬局薬剤師それぞれ が，後方支援や派遣される薬局薬剤師の地元での バックアップまで含めたそれぞれに適した災害支援 のあり方に気づくこと，本研究で明らかになつた知 見を基盤として薬局薬剤師を対象とした災害支援活 動に関する効果的な制度や教育プログラムが構築さ れること，もって薬局薬剤師にとって日々の研鑽と 備えのきっかけとなることを期待する.

謝辞本研究は，内閣府による「戦略的イノ ベーション創造プログラム（Cross-ministerial Strategic Innovation Promotion Program; SIP)」の助成 研究の一部として実施した（研究代表者：池内淳 子)。本研究を行うにあたり，アンケートの配布・ 回収にご尽力を頂いた神戸市薬剤師会事務局の方 タ，アンケートにご協力頂いた神戸市薬剤師会会員 の皆様に御礼申し上げます。

利益相反＼cjkstart開示すべき利益相反はない.

\section{REFERENCES}

1) Wakabayashi S., J. Kyorin Med. Soc., 46, 258-289 (2015).

2) Hirokawa S., Nakura H., Norose T., Yakugaku Zasshi, 134, 1-2 (2014).

3) Nakura H., Yakugaku Zasshi, 134, 3-6 (2014).

4) Tanno Y., Yakugaku Zasshi, 134, 19-23 
(2014) .

5) Yazawa K., J. Jpn. Primary Care Assoc., 38, 163-165 (2015).

6) Hara N., Tsuda H., Nagashima K., Kawasaki E., Matsuda T., Toyoda T., J. Jpn. Soc. Emergency Med., 17, 38-42 (2014).

7) Komada M., Yokoyama M., Yuasa T., Soeda S., J. Jpn. Soc. Emergency Med., 16, 810-816 (2013).

8) Uchikura K., Jpn., J. Drug Inform., 14, 117119 (2012).

9) Kato A., Katayama S., J. Nihon Univ. Med. Assoc., 7, 39-41 (2011).

10) Japan Pharmaceutical Association. "2016 nen Kumamoto jishin kanren joho.”: 〈http:// www.nichiyaku.or.jp/saigai2016/>, cited 5 May, 2016.

11) Kumamoto Pharmaceutical Association: $\langle$ http://www.kumayaku.or.jp/〉, cited 5 May, 2016.

12) "Yakuzaishi no tameno saigai taisaku manual.": 〈http: // www.nichiyaku.or.jp / saigai2016 / files / sr20160415.pdf $\rangle$, Japan Pharmaceutical Association Web, cited 5 May, 2016.

13) Nishizawa M., J. Jpn. Soc. Int. Med., 103, 1002-1007 (2014)

14) Yamaguchi T., Tanaka M., Tanaka A., Miyauchi T., Araki T., Namba H., Yakugaku Zasshi, 135, 1377-1386 (2015).

15) Moriyama Y., Yakugaku Zasshi, 134, 17-18 (2014) .

16) Ishibashi Y., Iwamoto M., Han Y.-H., Hayashi M., J. Natl. Inst. Public Health, 64, 81-86 (2015) .

17) Inayoshi M., Sakurai Y., Nakazawa K.,
Japanese Journal of National Medical Services, 59, 195-198 (2005).

18) Ministry of Health, Labour and Welfare. "Heisei 26 nen (2014 nen) ishi, shikaishi, yakuzaishi chosa no gaikyou.": 〈http://www. mhlw.go.jp/toukei/saikin/hw/ishi/14/index. html $\rangle$, cited 5 May, 2016.

19) Arai T., J. Kyorin Med. Soc., 47, 61-65 (2016).

20) Hirose H., Kishimoto K., Fukushima N., Jpn. J. Pharm. Health Care Sci., 39, 615-623 (2013).

21) Japan Pharmacist Society of Disaster Relief. "Saigai iryo shien yakuzaishi.": 〈http:// www.saigai-pharma.jp/>, cited 5 May, 2016.

22) Japanese Association for Disaster Medicine. "Saigai iryo nintei yakuzaishi kenshukai.": $\langle$ http://square.umin.ac.jp/jadm/〉, cited 5 May, 2016.

23) Matsuno S., "Practical Yakugaku Tokei Kaiseki," Kyoto Hirokawa Publishing INC., Tokyo, 2011, pp. 67-74.

24) Tsukinoki R., Murakami Y., Hayakawa T., Hashimoto S., Jpn. J. Public Health, 63, 1725 (2016).

25) Harada, N., J. Jpn. Primary Care Assoc., 38, 170-175 (2015).

26) Yamakawa M., Khruekarnchana P., Yorifuji T., Omasa T., Doi H., J. Int. Health, 27, 183189 (2012).

27) Nishinippon Shimbun. "Okusuri techo saigaiji keitai o fukuyakujoukyouhaaku ni hitsuyou.": 〈http://www.nishinippon.co.jp/feature/life_topics/article/249801 $\rangle$, cited 9 June, 2016. 